\title{
REVIEW
}

\section{Relationship between aerobic and anaerobic power, and Special Judo Fitness Test (SJFT) in elite Iranian male judokas}

\author{
A. Farzaneh Hesari ${ }^{a, *}$, B. Mirzaei ${ }^{b}$, S. Mahdavi Ortakand ${ }^{a}$, A. Rabienejad ${ }^{c}$, \\ P.T. Nikolaïdis ${ }^{d}$ \\ a Department of Physical Education and Sport Sciences, Sabzevar Tarbiat Moallem University, Sabzevar, Iran \\ ${ }^{b}$ Department of Physical Education and Sport Sciences, Guilan University, Rasht, Iran \\ c Gorgan Branch, Islamic Azad University, Gogan, Iran \\ ${ }^{\mathrm{d}}$ Exercise Physiology Laboratory, Nikaia, Greece
}

Received 26 November 2012; accepted 15 July 2013

Available online 22 September 2013

\section{KEYWORDS}

Field and laboratory exercise tests;

Martial arts

\begin{abstract}
Introduction: The purpose of this study was to assess the relationship between aerobic and anaerobic power, and special judo fitness test in elite male judokas.

Method: Nineteen elite Judokas [age 24.3 (3.1) yr, height $1.78(.06) \mathrm{m}$, body mass $76.4(11.2)$ $\mathrm{kg}$, body mass index $20.2(3.6) \mathrm{kg} \cdot \mathrm{m}^{-2}$ and body fat $\left.11.0(1.8) \%\right]$ performed a graded exercise test in treadmill, the Wingate anaerobic test for arms and the special judo fitness test. The graded exercise test in treadmill estimated maximal oxygen uptake $\left(\mathrm{VO}_{2} \mathrm{max}\right)$ and the Wingate anaerobic test assessed peak and mean power, descriptors of short-term power output and local muscular endurance respectively.

Results: The index of special judo fitness test was in inverse direct relationship with $\mathrm{VO}_{2}$ max $(r=-.87, p<.01)$, peak power $(r=-.74, p<.01)$ and mean power $(r=-.62, p<.05)$.

Discussion: Based on these findings, it was showed that the special judo fitness test is a field test that describes chiefly aerobic power, and in a lesser degree short-term power output and local muscular fatigue. Therefore, its further use from judo coaches and fitness trainers as a measure to monitor aerobic power is recommended, and the need for a field test that will describe anaerobic power is highlighted.

(c) 2012 Consell Català de l'Esport. Generalitat de Catalunya. Published by Elsevier España, S.L. All rights reserved.
\end{abstract}

\footnotetext{
* Corresponding author.

E-mail address: aminak101@yahoo.com (A. Farzaneh Hesari).
} 


\section{PALABRAS CLAVE}

Pruebas de ejercicio de campo y laboratorio; Artes marciales
Relación entre potencia aeròbica y anaeròbica y el Special Judo Fitness Test (SJFT) en judocas masculinos iraníes de élite

\section{Resumen}

Introducción: El objetivo de estudio fue la evaluación de la relación entre las potencias aeróbica y anaeróbica, así como la prueba especial de aptitud física para el judo en los judokas masculinos de élite.

Método: Diecinueve judokas de élite-edad 24,3 $(3,1)$ años, altura 1,78 $(0,06) \mathrm{m}$, masa corporal $76,4(11,2) \mathrm{kg}$, índice de masa corporal $20,2(3,6) \mathrm{kg} \cdot \mathrm{m}^{2}$ y grasa corporal $11,0(1,8) \%$-realizaron una prueba de esfuerzo en cinta, la prueba anaeróbica de Wingate para brazos, y la prueba especial de aptitud física para el judo. La prueba de esfuerzo en cinta calculó la captación máxima de oxígeno (VO2max) y la prueba anaeróbica de Wingate evaluó la potencia máxima y media, que describen el rendimiento a corto plazo y la resistencia muscular local, respectivamente. Resultados: El índice de la prueba especial de aptitud física para el judo guardó una relación directa inversa al índice VO2max $(r=-0,87, p<0,01)$, potencia máxima $(r=-0,74, p<0,01)$ y potencia media $(r=-0,62, p<0,05)$.

Discusión: Basándonos en estos hallazgos se ha demostrado que la prueba especial de aptitud física para el judo es una prueba de campo que describe principalmente la potencia aeróbica, y en menor grado el rendimiento a corto plazo y la fatiga muscular local. Por tanto, se recomienda su uso a los entrenadores de judo y a los monitores de entrenamiento físico como medida de supervisión de la potencia aeróbica, resaltando la necesidad de una prueba de campo que describa la potencia anaeróbica.

(c) 2012 Consell Català de l'Esport. Generalitat de Catalunya. Publicado por Elsevier España, S.L. Todos los derechos reservados.

\section{Introduction}

Judo is an Olympic sport that requires high physical, psychological and technical preparation. ${ }^{1}$ Competitive judo can be described as a combative, high intensity sport in which the athlete attempts to throw the opponent onto his back or to control him during groundwork combat. Both attempts depend on specific techniques and tactical skills supported by good physical fitness. ${ }^{2}$ Judo techniques, such as throws, armlocks, choking and immobilization techniques, tax both anaerobic alactic and lactic energy transfer systems. ${ }^{3}$ Considering the contest duration and the number of contests during a tournament, aerobic capacity is also important in terms of better use of the judoka's system and the prompt recuperation process. ${ }^{4}$

The evaluation of physical characteristics is an important part of the training process because it gives information about the variables that need improvement and about the effectiveness of a given training program. ${ }^{5}$ Physiological testing is commonly used to assess the overall fitness level of the athletes and to set guidelines for individualized training. ${ }^{6}$ In laboratory setting, aerobic power typically is assessed through maximal or submaximal tests, performed on ergometer, while anaerobic power is assessed through maximal tests (e.g., Wingate anaerobic test, Force-velocity test and Bosco test). Although laboratory tests provide valid and reliable results, they cannot reproduce realistically the sport movement patterns, and therefore the need for sportspecific test in judo has been evolved. Several field tests have been proposed. Among them, a judo-specific ability test, consisting by 10 stations, in which adolescent judokas performed physical ability and skill tasks, did not correlate with performance ranking, and therefore it was not sensitive enough to accurately measure talent. ${ }^{7}$
On the other hand, the special judo fitness test (SJFT), which has been proposed by Sterkowicz, is considered as useful training tool. ${ }^{8}$ Blood lactate concentration after the SJFT was very similar to that obtained after judo combat, indicating similar metabolic responses in these situations. ${ }^{9}$ Sterkowicz and Franchini observed that elite Polish judokas (medalist in the National Championship) presented a better SJFT index compared with athletes representing a lower sport level and that competitors of light weights categories presented a better index than judokas of heavier categories. ${ }^{10}$ In addition, Franchini et al. found that athletes with superior age to 16 years of age submitted to the same training type tend to have similar performance in the SJFT. ${ }^{11}$

To the best of our knowledge, the association between SJFT with laboratory assessment methods of physical fitness has not been studied. Therefore, the purpose of this study was to assess the relationship between aerobic and anaerobic power and results of SJFT in Iranian male national judo athletes.

\section{Materials and methods}

\section{Participants}

In this investigation, a descriptive-correlation design was used to examine the association between laboratory measures of aerobic and anaerobic power, and the SJFT. The local Institutional Review Board approved and National Judo Federation supported the study. Written informed consent was obtained from all athletes after verbal explanation of the experimental design and potential risks of study. Exclusion criteria included history of any chronic medical conditions 
and use of any medication. Nineteen elite judokas, including 11 members of Iranian National Team and eight nationallevel athletes, who were invited to the national training camps, volunteered for our study [age 24.3 (3.1) yr, mean (SD), height $1.779(.063) \mathrm{m}$, body mass $76.4(11.2) \mathrm{kg}$, body mass index $20.2(3.6) \mathrm{kg} \cdot \mathrm{m}^{-2}$ and body fat $\left.11.0(1.8) \%\right]$. All participants competed to official games in weight categories $-60 \mathrm{~kg},-66 \mathrm{~kg},-73 \mathrm{~kg},-81 \mathrm{~kg}$ and $-90 \mathrm{~kg}$.

\section{Measures}

The study was conducted during four consecutive days. In the first day, anthropometric and body composition data were recorded, and in the following days, SJFT, Wingate anaerobic test (WAnT) and graded exercise test (GXT) were performed respectively, always after a guided standardized 15-min warm-up. An electronic weight scale (HD-351 Tanita, Illinois, USA) was employed for body mass measurement (in the nearest $.1 \mathrm{~kg}$ ), a portable stadiometer (SECA, Leicester, UK) for stature (.001 $\mathrm{m})$, a body composition analyzer (TBF410 Tanita, Illinois, USA) for percentage of body fat (BF), and body mass index was calculated.

\section{Procedures}

Maximal oxygen uptake $\left(\mathrm{VO}_{2} \max \right)$ was estimated by a GXT (Bruce protocol test) on a treadmill (HC1200 Technogym, Gambettola, Italy), which included six 3-min stages against incremental speed (from $2.74 \mathrm{~km} \cdot \mathrm{h}^{-1}$ to $8.85 \mathrm{~km} \cdot \mathrm{h}^{-1}$ ) and inclination (from $10 \%$ to $20 \%$ ). Total time $(T)$ was recorded in minutes and $\mathrm{VO}_{2}$ max was calculated as $\mathrm{VO}_{2} \max$ $\left(\mathrm{mL} \cdot \mathrm{kg}^{-1} \cdot \mathrm{min}^{-1}\right)=14.8-1.379 \cdot T+.451 \cdot T 2-.012 \cdot T 3$.

Anaerobic power was measured by the WAnT. This test was performed on an arm-cranking ergometer (881E Monark, Varberg, Sweden). Braking force for the 30-s WAnT was determined by the product of body mass in $\mathrm{kg}$ by .05 . Participants were instructed before the test that they should pedal as fast as possible and they were verbally encouraged throughout the test. Compared with the other tests, WAnT has the advantage that it provides information about both alactic and lactic anaerobic energy transfer system. The main indices of this test are: (a) peak power (Ppeak), the highest power elicited from the test taken as the average power of any 5-s period and (b) mean power (Pmean), the average power during the 30 -s test, minimal power. Regarding the taxing of human energy transfer systems during the test, Ppeak is considered as a descriptor of short-term power output that relies mainly upon adenosine triphosphate-creatine phosphate (alactic anaerobic system), and Pmean as a descriptor of local muscular endurance that relies mainly upon anaerobic glycolysis resulting in lactate production (lactic anaerobic system).

Athletes performed the sport-specific test proposed by Sterkowicz, according to the following protocol: two judokas with similar height and body mass (same category) are positioned at $6 \mathrm{~m}$ distance from one another, while the test executor (tori) is $3-\mathrm{m}$ from the judokas. The procedure is divided into three periods: 15-s (A), 30-s (B), and 30-s (C) with 10-s intervals among them. During each period, the executor throws partners using the ippon-seoi-nage technique, as many times as possible. Heart rate (HR) is recorded immediately and one minute after the cessation of the test by HR monitor (Sport-tester Polar Electro, Kempele, Finland). On the basis of the obtained results, the index $\left(I_{\mathrm{SJFT}}\right)$ was calculated:

$$
\begin{aligned}
I_{\mathrm{SJFT}}= & (\text { HR after effort }+ \text { HR after } 1 \text { min since effort } \\
& \quad \text { completed }) /[\text { sum of throws }(\text { series } A+\text { series } B \\
+ & \text { series } C)]
\end{aligned}
$$

\section{Analysis}

All statistical analyses were performed with using SPSS 13.0 (SPSS Inc., Chicago, IL, USA). Descriptive statistics, including means and standard deviations (SD) for the outcome variables of interest, were computed. Pearson product moment correlation $(r)$ was used to determine the degree of association among selected variables. Significance level was set at alpha $=.05$.

\section{Results}

With regard to the parameters of SJFT, throws in series A were $6.3(.6)$ [mean (SD)], in series B $10.9(.7)$, in series C 10.3 (1.0) and their sum was 27.5 (1.8). Heart rate (HR) in the end of series C was 176.8 (6.8) beats. min $^{-1}$ and one minute after the end of series C HR was 142.5 (10.5) beats $\mathrm{min}^{-1}$. The $I_{\text {SJFT }}$ was 11.7 (1.0). The estimated $\mathrm{VO}_{2}$ max was $54.4(4.5) \mathrm{ml} \cdot \mathrm{kg}^{-1} \cdot \mathrm{min}^{-1}$, while the Ppeak and Pmean were $7.8(.4) \mathrm{W} \cdot \mathrm{kg}^{-1}$ and $5.9(.6) \mathrm{W} \cdot \mathrm{kg}^{-1}$ respectively.

The correlation analysis between anthropometric characteristics and the SJFT revealed an inverse association of height with the number of throws in series $C(r=-.68$, $p<.05)$, as well as with the sum of throws $(r=-.64, p<.05)$. A negative correlation was also observed between weight and the number of throws in series $A(r=-.67, p<.05)$, the number of throws in series $C(r=-.68, p<.05)$ and the sum of throws $(r=-.71, p<.05)$. Table 1 showed the association between SJFT, $\mathrm{VO}_{2}$ max and anaerobic power.

\section{Discussion}

The close association between physical characteristics and SJFT was in agreement with early studies on judokas

Table 1 Association between $\mathrm{VO}_{2}$ max, anaerobic power and SJFT of judokas.

\begin{tabular}{lccc}
\hline & $\mathrm{VO}_{2} \mathrm{max}$ & Ppeak & Pmean \\
\hline Series A throws & .50 & $.53^{*}$ & .43 \\
Series B throws & 35 & .33 & .23 \\
Series C throws & $.86^{\dagger}$ & $.74^{\dagger}$ & $.63^{\dagger}$ \\
Sum of throws & $.78^{\dagger}$ & -.26 & -.28 \\
HR after series C & $.2^{\dagger}$ & $-.58^{*}$ & $-.65^{\dagger}$ \\
HR after 1 min rest & $-.89^{\dagger}$ & $.71^{\dagger}$ & $.53^{*}$ \\
$I_{\text {SJFT }}$ & $-.87^{\dagger}$ & $-.74^{\dagger}$ & $-.62^{*}$ \\
\hline${ }^{*} p<.05$. & & & \\
${ }^{\dagger} p<.01$. & & &
\end{tabular}


that highlighted the importance of height and weight for this sport. ${ }^{12,13} I_{\text {SJFT }}$ illustrates the level of performance at the SJFT, the higher the performance, the lower the index. Participants had similar values of $I_{\text {SJFT }}(11.7 \pm 1.0)$ with Polish judokas $(11.6 \pm 1.2)^{14}$ and better values than Brazilian judokas (13.2 \pm 1.55$).{ }^{11} \mathrm{HR}$ at the end of the test and one minute after the test was comparable with previous studies. ${ }^{11,14} \mathrm{VO}_{2} \max \left(54.4 \pm 4.5 \mathrm{ml} \cdot \mathrm{kg}^{-1} \cdot \mathrm{min}^{-1}\right)$ in our sample was lower than Canadian judokas' corresponding values $\left(59.2 \pm 5.2 \mathrm{ml} \cdot \mathrm{kg}^{-1} \cdot \mathrm{min}^{-1}\right) .^{2}$ In other relevant research, $\mathrm{VO}_{2}$ max values in state and national level judokas was $59.8 \pm 3.6 \mathrm{ml} \cdot \mathrm{kg}^{-1} \cdot \mathrm{min}^{-1},{ }^{15}$ in a Olympic team $52.9 \pm 4.4 \mathrm{ml} \cdot \mathrm{kg}^{-1} \cdot \mathrm{min}^{-1} \cdot{ }^{16}$ It has been suggested that $\mathrm{VO}_{2}$ max ranges between 50 and $60 \mathrm{ml} \cdot \mathrm{kg}^{-1} \cdot \mathrm{min}^{-1}$ in judo. ${ }^{6}$ A possible explanation for such discrepancy could be the choice of assessment method of aerobic power.

With regard to anaerobic power, Ppeak $\left(7.8 \pm .4 \mathrm{~W} \cdot \mathrm{kg}^{-1}\right)$ and Pmean $\left(5.9 \pm .6 \mathrm{~W} \cdot \mathrm{kg}^{-1}\right)$ of participants were also in agreement with previous studies. For instance, Ppeak and Pmean in Canadian judokas were $7.7 \pm 0.9 \mathrm{~W} \cdot \mathrm{kg}^{-1}$ and $5.7 \pm 0.7 \mathrm{~W} \cdot \mathrm{kg}^{-1}$, respectively, ${ }^{2}$ while Ppeak and Pmean in Brazilian judokas were $8.1 \pm 0.8 \mathrm{~W} \cdot \mathrm{kg}^{-1}$ and $6.2 \pm 0.7 \mathrm{~W} \cdot \mathrm{kg}^{-1}$ respectively. ${ }^{11}$ Maximal anaerobic power greatly affects the competitive performance of a judoka. ${ }^{17}$ WAnT is a test that can discriminate athletes based on the level of expertise. For example, national and university varsity team judokas scored better in this test than juniors. ${ }^{17}$

Generally, elite judokas scored better in physical fitness tests and in sport-specific tests than their sub-elite counterparts. ${ }^{18}$ Previous research suggested that coordination/strength, speed, flexibility and balance, muscle mass and bone volume, and endurance judo performance as expressed by the fight winning score were related to judo performance. ${ }^{19}$ In an analysis of junior judokas, their final national championship achievement was associated with endurance and strength, and not with anthropometry. ${ }^{20}$

To sum up, our findings with regard the aerobic and anaerobic profile of elite judokas confirmed previous observations about their high physical fitness level. However, what was the most important finding was the strong correlation between aerobic and anaerobic power with performance in the SJFT. It was showed that the SJFT is a field test that describes chiefly aerobic power, and in a lesser degree short-term power output and local muscular fatigue. Therefore, its further use from judo coaches and fitness trainers as a measure to monitor aerobic power is recommended, and the need for a field test that will describe anaerobic power is highlighted. Moderate correlations between SJFT and indices of aerobic and anaerobic power were indicated in the past in a study in which the number of throws in the SJFT was correlated with anaerobic threshold velocity $(r=.60, p<.01)$, peak velocity in incremental test $(r=.70, p<.01)$ and countermovement jump $(r=.74$, $p<.01){ }^{21}$

The significant correlation of SJFT with both aerobic and anaerobic power was not unexpected, as there are high requirements for both in judo. Judo training improves both aerobic and anaerobic performance and these changes were associated with changes in heart structure and function as compared to non-trained control. ${ }^{22}$ In addition, Gariod et al. suggested that judo players with a higher $\mathrm{VO}_{2}$ max presented a faster creatine phosphate $(\mathrm{CP})$ resynthesis compared with judo players with a lower $\mathrm{VO}_{2}$ max. ${ }^{23}$ Together with the faster $\mathrm{CP}$ resynthesis, a faster lactate removal and $\mathrm{pH}$ recovery in individuals with higher aerobic power could benefit the recovery process. ${ }^{24}$

\section{Conclusions}

The agreement of our findings with other studies on elite judokas stresses the need for specific physiological characteristics in these athletes. The moderate to high correlations between SJFT and physical fitness confirmed the validity of SJFT as a field test in judo. Therefore, judo coaches should employ this test to monitor their athletes' progress.

\section{Conflict of interests}

Authors declare that they don't have any conflict of interests.

\section{Acknowledgement}

We thank all athletes who volunteered for this study.

\section{References}

1. Little NG. Physical performance attributes of junior and senior women, juvenile, junior and senior men judokas. J Sports Med Phys Fitness. 1997;31:510-20.

2. Thomas SG, Cox MH, Legal YM, Verde TJ, Smith HK. Physiological profiles of the Canadian National Judo Team. Can J Sport Sci. 1989;14:142-7.

3. Laskowski R. Training loads and physical capacity in female practicing judo. Gdańsk: Awfis; 2007.

4. Ikai M, Haga S, Kaneko M. The characteristic of physical fitness of judoists from the viewpoint of respiratory and cardiovascular functions. Bull Assoc Sci Stud Judo Kodokan Rep. 1987;4:47-55.

5. Lidor R, Melnik Y, Bilkevitz A, Falk B. The ten station judo ability test: a test of physical and skill components. Strength Cond J. 2006;28:18-20.

6. Franchini E, Nunes AV, Moraes JM, Del Vecchio FB. Physical fitness and anthropometrical profile of the Brazilian male judo team. J Physiol Anthropol. 2007;26:59-67.

7. Lidor R, Melnik Y, Bilkevitz A, Arnon M, Falk B. Measurement of talent in judo using a unique: judo-specific ability test. J Sports Med Phys Fitness. 2005;45:32-7.

8. Sterkowicz S. Special judo fitness test. Antropomotoryka. 1995; 12:29-44.

9. Franchini E, Nakamura FY, Takito MY, Kiss MA, Sterkowicz S. Specific fitness test developed in Brazilian judoists. Biol Sport. 1998;15:165-70.

10. Sterkowicz S, Franchini E. Specific fitness of elite and novice judoists. J Hum Kinetics. 2001;6:44-52.

11. Franchini E, Nakamura FY, Takito MY, Kiss MA, Sterkowicz S. Special judo fitness test in juvenile: junior and senior Brazilian judo players. Biol Sport. 2005;7:11-8.

12. Farmosi I. Body-composition: somatotype and some motor performance of judoists. J Sports Med Phys Fitness. 1980;20:431-4.

13. Claessens A, Beunen G, Wellens R, Geldof G. Somatotype and body structure of world top judoists. J Sports Med Phys Fitness. 1987;27:105-13.

14. Sterkowicz S, Franchini E. Special judo fitness test. Warszawa: AWF; 2006.

15. Santos L, González V, Iscar M, Brime JI, Frnandez-Rio J, Egocheaga $\mathrm{J}$, et al. A new individual and specific test to 
determine the aerobic-anaerobic transition zone (Santos Test) in competitive judokas. J Strength Cond Res. 2010;24:2419-28.

16. Sbriccoli P, Bazzucchi I, Di Mario A, Marzattinocci G, Felici F. Assessment of maximal cardiorespiratory performance and muscle power in the Italian Olympic judoka. J Strength Cond Res. 2007;21:738-44.

17. Kim J, Cho HC, Jung HS, Yoon JD. Influence of performance level on anaerobic power and body composition in elite male judoists. J Strength Cond Res. 2011;25:1346-54.

18. Almansba R, Franchini E, Sterkowicz S. Uchi-komi avec charge, une approche physiologique d'un nouveau test spécifique au judo. Sci Sports. 2007;22:216-23.

19. Krstulović S, Zuvela F, Katić R. Biomotor systems in elite junior judoists. Coll Antropol. 2006;30:845-51.
20. Krstulović S, Sekulić D, Sertić H. Anthropological determinants of success in young judoists. Coll Antropol. 2005;29:697-703.

21. Detanico D, Dal Pupo J, Franchini E, Giovana dos Santos S. Relationship of aerobic and neuromuscular indexes with specific actions in judo. Sci Sports. 2012;27:16-22.

22. Laskowski R, Wysocki K, Multan A, Haga S. Changes in cardiac structure and function among elite judoists resulting from longterm judo practice. J Sports Med Phys Fitness. 2008;48:366-70.

23. Gariod L, Favre-Juvin A, Novel V, Majean H, Rossi A. Évaluation du profil énergétique des judokas par spectroscopie. Sci Sports. 1995;10:201-7.

24. Tomlin DL, Wenger HA. The relationship between aerobic fitness and recovery from high intensity intermittent exercise. Sport Med. 2001;31:1-11. 